\title{
Physical Activity, Cardiorespiratory Fitness, Dietary Content, and Risk Factors That Cause a Predisposition Towards Cardiovascular Disease
}

\author{
Dartagnan Pinto Guedes, Joana Eisabete Ribeiro Pinto Guedes
}

\author{
Londrina, PR - Brazil
}

\begin{abstract}
Objective - To analyze associations between levels of physical activity, cardiorespiratory fitness, dietary content, and risk factors that cause a predisposition towards cardiovascular disease.
\end{abstract}

Methods - Sixty-two individuals aged between 20 and 45 years were evaluated. Levels of physical activity were established by estimates of energy demand corresponding to everyday activity; indices for cardiorespiratory fitness were obtained from estimates of maximal oxygen consumption; information about dietary content was obtained from dietary records kept on seven consecutive days. To indicate risk factors that cause a predisposition towards cardiovascular disease, use was made of body mass indexes, waist-hip circumference relationships, levels of arterial pressure and of plasma lipid-lipoprotein concentration. To establish associations between the variables studied, multiple regression analysis was used.

Results - Physical activity levels and cardiorespiratory fitness levels were inversely correlated with the amount and distribution of body fat and arterial pressure. Taken together, the two variables were responsiblefor between $16 \%$ and $19 \%$ of the variation in arterial pressure. Total and saturated fat ingestion was associated with higher serum lipid levels. Both dietary components were responsible for between $49 \%$ and $61 \%$ of the variation in LDL-cholesterol.

Conclusion-High ingestion of food rich in total and saturated fat and decreased levels of physical activity and of cardiorespiratory fitness are associated with an increased risk of cardiovascular disease, which supports previous data.

Key words: body fat, blood pressure, plasma lipids, lipoproteins

Universidade Estadual de Londrina. Apoio do $\mathrm{CNPq}$

Mailing address: Dartagnan Pinto Guedes - Av. Maringá, 725/304 - 86060-000, Londrina, PR - E-mail: darta@sercomtel.com.br
The consensus among specialists is that cardiovascular diseases are multifactorial in origin, resulting from socalled risk factors ${ }^{1}$. Once risk factors are understood to be causal agents resulting in a predisposition towards heart diseases, monitoring of these risk factors aids in the identification of signals that, if modified, may attenuate or even reverse the evolution of heart diseases.

Compromising levels of plasma lipids-lipoproteins, high arterial pressure, and excessive fat/body weight ratios are considered biological risk factors of major significance in cardiovascular disease. These factors do not act alone but as a whole, causing an exponential rise in the possibility of cardiovascular accidents.

Physical activity and appropriate dietary habits are considered major mechanisms for protection from the surge and progression of risk factors that cause a predisposition towards cardiovascular disease ${ }^{2-6}$. Therefore, differences regarding everyday performance of physical activity, levels of cardiorespiratory fitness, and dietary content have been frequently used in attempts to explain variations in the prevalence of cardiovascular disease in different population groups $^{7-10}$.

Incentives to increase physical activity and use of an adequately balanced dietary regime have played a significant role in various programs aimed at the prevention and control of heart diseases. Yet, although capable of influencing risk factors by a multiplicity of interacting metabolic, functional, and morphologic adaptations, the relative contributions of effective physical activity, cardiorespiratory fitness, and diet on risk factor variability ave not been clearly defined. Thus, studies aimed at the evaluation of the extent of these influences on specific segments of different populations are still required. It is expected that such a search will dentify, in a more explicit manner, preventive and therapeutic measures associated with cardiovascular diseases.

The objective of the study was to search for an explanation for variations observed in information associated with biological risk factors that cause a predisposition 
towards cardiovascular disease as functions of the levels of physical activity, cardiorespiratory fitness, and dietary content in adult, middle-aged individuals of either sex.

\section{Methods}

The study included employees of the administrative sector of the State University of Londrina, who were participating in physical exercise programs offered by the Center for Physical Education and Sports at the institution during the second semester of 1995 . The study sample was composed of subjects involved in physical exercise, according to five basic criteria: a) to be between 20 and 45 years of age; b) to have been participating in the physical exercise programs for at least six months; c) to have been nonsmokers during the preceding five years; d) to not be using antihypertensives or similar drugs; e) to not be on special dietary regimens. The definitive sample was composed of 62 subjects, 21 males and 41 females.

The indicators of biological risk factors that cause a predisposition towards cardiovascular disease were information on amount/distribution of body fat, resting arterial blood pressure, and circulating lipid blood levels.

Estimates of amounts and distribution of body fat were obtained by calculating body mass index based on the ratio between body weight and hight squared $\left(\mathrm{kg} / \mathrm{m}^{2}\right)$. To determine hight, a stadiometer calibrated to $0.1 \mathrm{~cm}$ and to verify body weight, anthropometric balance divided into $100 \mathrm{~g}$ according to Gordon et $\mathrm{al}^{11}$ were used. Waist and hip girth were measured with a flexible, decimal anthropometric steel band, following the standardization suggested by Callaway et al ${ }^{12}$.

Systolic and diastolic arterial pressures of the left arm were ascertained in seated subjects after a $5 \mathrm{~min}$ rest period, using a mercury column sphygmomanometer. Systolic arterial pressure corresponded to Korotkoff's phase 1 and diastolic pressure to phase $\mathrm{V}$, or the disappearance of sound. Averages of two measurements were used for calculations.

Plasma lipid estimations were performed on $10-\mathrm{mL}$ venous blood samples collected from the arm between 7:00 and 8:00 AM, after the subjects had fasted for 10-12 h. Serum was immediately centrifuged, and triglyceride, total cholesterol, and low- and high-density lipoprotein fractions were determined. Serum total cholesterol was determined spectrophotometrically with the enzymatic cholesterol oxidase/ peroxidase method. HDL- and LDL-cholesterol were determined, respectively, with the reactive precipitant and Friedewald's formula ${ }^{13}$. Serum triglycerides were determined with the glycerol enzymatic method.

Levels of physical activity were established by estimating the energy demand corresponding to everyday physical activity, with Bouchard and collaborator's retrospective everyday activity auto-recording instrument. Subjects filled out their own records over a consecutive seven-day period. For this, the day was divided into 96 periods of $15-$ min duration, subjects being instructed to record the type of activity performed during each period. Estimates of energy demand per kg of body weight were established from the caloric cost of the physical activity performed during each day ( $\mathrm{kcal} / \mathrm{kg} /$ day). Averaged seven-day energy demands recorded over seven days were used for calculations.

Information concerning dietary content was obtained from dietary records. Subjects were instructed to identify every food and drink and the amounts ingested over a period of seven consecutive days. From this information, the average energy supply/day/per kg of body weight (kcal/kg/ day) and the average amounts (g/day) of protein, carbohydrate, and fat, and of saturated, monounsaturated, polyunsaturated fat and cholesterol were determined. Caloric equivalents and nutritional proportions of the food were established with the software Program of Nutrition Support - version -2, created by the Informatics Health Center of the Escola Paulista de Medicina.

Indicators of cardiorespiratory fitness were obtained from estimates of maximal oxygen consumption at maximal stress on the treadmill, according to Bruce's Protocol ${ }^{15}$. The time period required to attain theoretical maximal heart rate (220-age) was used to estimate maximal oxygen consumption. For subjects unable to reach theoretical maximal heart rate, the duration of the stress test was used as an index. Indications for stopping the test were those recommended by the American College for Sports Medicine ${ }^{16}$.

The statistical treatment of the information obtained was performed with the computerized Statistical Analysis System - version 3.0 package.

The set of variables that, when combined, best explained the variations in risk factor indicators was detected with stepwise multiple regression analysis, having as independent variables information on levels of physical activity, cardiorespiratory fitness, and dietary content. The predictive contribution of each variable was analyzed with the statistical significance test, involving beta coefficients presented by the regression models.

\section{Results}

Table I shows statistical information on the variables analyzed. Estimates on energy demand per $\mathrm{kg}$ of body weight, equivalent to everyday physical activity, showed similar average values for both sexes. Energy supply and demand of each subject showed that at the moment of the collection of information, $20 \%$ of men and $35 \%$ of women had an energy surplus. Maximal oxygen consumption, an indicator of cardiorespiratory fitness, did not show statistically significant differences between sexes, which is in agreement with evidence in the literature ${ }^{17}$; nevertheless, men showed higher mean values compared with women.

Results concerning dietary content showed statistical differences between sexes. Considering nutritional recommendations in the literature ${ }^{18}$, the analyzed sample showed an increased ingestion of protein and fat, in particular of the saturated type. Yet, the ingestion of mono- and polyunsaturated fat was less than the recommended amounts.

In relation to the risk factors that cause a predisposition towards cardiovascular disease, average amounts found 
pointed to statistical differences in favor of men for body weight index, waist/hip circumference, systolic and diastolic arterial pressure, and triglycerides. Total, LDL, and HDL cholesterol values were similar between sexes. When compared with values suggested by the Brazilian Society of Cardiology ${ }^{19}$, plasma lipid concentrations associated with increased risk of cardiovascular disease- were the same in approximately $12 \%$ of the samples studied; $12.3 \%$ had LDLcholesterol values higher than $160 \mathrm{mg} / \mathrm{dL} ; 12.9 \%$ had HDLcholesterol $<35 \mathrm{mg} / \mathrm{dL}$, and $10.7 \%$ had triglyceride concentrations $>200 \mathrm{mg} / \mathrm{dL}$. In addition, $13.9 \%$ of the sample analyzed had diastolic and systolic arterial pressure levels $>90$ or $>140 \mathrm{mmHg}$, respectively. Concerning the amount/distribution of body fat, $21 \%$ of the subjects were overweight (body mass index $>28 \mathrm{~kg} / \mathrm{m}^{2}$ ), and $30.6 \%$ demonstrated increased centripetal fat concentration (waist/hip circumference $>0.80$ for women and $>0.90$ for men).

Results of multiple regression analysis are presented in Table II. Independent variables, which did not demonstrate a statistically significant predictive contribution, were disregarded in the setting up of the regression models. The results obtained pointed to total and saturated dietary fat amounts, energy demand corresponding to everyday physical activity, and maximal oxygen consumption as the most important variables in biological risk factor variations that cause a predisposition towards cardiovascular disease. Taken together, these variables were responsible for the totality of the variation explained by the entire aggregate of independent variables. The inclusion of other information regarding dietary content in the predictive model did not offer any additional information to be taken into account in statistical terms.

Indicators of physical activity and cardiorespiratory fitness demonstrated a higher predictive power when associated with the amount/distribution of body fat and arterial pressure levels. The findings show a systematic, positive impact of energy demand/day and maximal oxygen consumption on these variables, confirming the expectation that the more active the subjects, the better the body adiposity and arterial pressure profiles. Everyday energy demand and maximal oxygen consumption either together or isolated explain between $27 \%$ and $73 \%$ of the variations in the amounts/distribution of body fat, and between $16 \%$ and $19 \%$ of the variations observed in arterial pressure indexes.

Information on total and saturated fat ingestion was that most closely identified with plasma lipid-lipoprotein estimates, the greatest prominence given to LDL-cholesterol and triglyceride levels. Taken together, these two pieces of dietary information explain about $49 \%$ and $61 \%$ of the variations detected in the concentrations of LDL-cholesterol in men and women, respectively. In the case of triglycerides, despite maximal oxygen consumption having been pointed out as an element of better predictive power, when saturated fat ingestion was included in the regression model, the capacity of explanation of the model was raised to levels close to $22 \%-28 \%$.

The results obtained reveal that the association between physical activity, cardiorespiratory fitness, and biological risk factors that cause a predisposition towards cardiovascular disease was more strong among women and,

\begin{tabular}{|c|c|c|c|c|}
\hline Variable & $\begin{array}{l}\text { Women } \\
(\mathrm{n}=41)\end{array}$ & $\begin{array}{c}\text { Men } \\
(n=21)\end{array}$ & Teste "t" & $\mathrm{p}<\mathrm{t}$ \\
\hline \multicolumn{5}{|l|}{ Physical activity } \\
\hline \multicolumn{4}{|l|}{ Cardiorespiratory fitness } & 0.086 \\
\hline \multicolumn{5}{|l|}{ Diet content } \\
\hline Energy supply (kcal/kg/day) & $36.78 \pm 4.71$ & $34.06 \pm 3.66$ & 2.310 & 0.024 \\
\hline Proteins (g/day) & $97.92 \pm 28.81$ & $123.57 \pm 32.98$ & 3.158 & 0.003 \\
\hline Carbohidrates (g/day) & $250.55 \pm 55.42$ & $305.68 \pm 88.94$ & 3.002 & 0.004 \\
\hline Total fat (gr/day) & $85.39 \pm 29.08$ & $104.67 \pm 32.83$ & 2.365 & 0.021 \\
\hline Saturated fat (gr/day) & $32.38 \pm 10.13$ & $46.55 \pm 12.86$ & 4.751 & 0.000 \\
\hline Monoinsaturated fat (gr/day) & $20.45 \pm 11.54$ & $28.08 \pm 17.28$ & 2.072 & 0.043 \\
\hline Polynsaturated fat (gr/day) & $14.84 \pm 10.60$ & $24.95 \pm 9.14$ & 3.717 & 0.000 \\
\hline Cholesterol (g/day) & $263.15 \pm 139.82$ & $404.42 \pm 158.84$ & 3.595 & 0.000 \\
\hline \multicolumn{5}{|l|}{ Risk factors } \\
\hline $\operatorname{BMI}\left(\mathrm{kg} / \mathrm{m}^{2}\right)$ & $23.87 \pm 3.45$ & $26.81 \pm 2.41$ & 3.487 & 0.000 \\
\hline WHR & $0.81 \pm 0.01$ & $0.93 \pm 0.05$ & 6.984 & 0.000 \\
\hline $\mathrm{DBP}(\mathrm{mmHg})$ & $76.90 \pm 10.90$ & $84.29 \pm 8.27$ & 2.727 & 0.008 \\
\hline $\mathrm{SBP}(\mathrm{mmHg})$ & $114.34 \pm 16.91$ & $127.57 \pm 10.08$ & 3.290 & 0.002 \\
\hline $\mathrm{TC}(\mathrm{mg} / \mathrm{dl})$ & $187.51 \pm 48.27$ & $204.10 \pm 42.87$ & 1.328 & 0.189 \\
\hline HDL-C (mg/dl) & $51.83 \pm 13.20$ & $48.57 \pm 7.71$ & 1.042 & 0.302 \\
\hline LDL-C (mg/dl) & $120.10 \pm 37.88$ & $127.48 \pm 29.03$ & 0.782 & 0.437 \\
\hline $\mathrm{TG}(\mathrm{mg} / \mathrm{dl})$ & $81.80 \pm 46.76$ & $146.14 \pm 57.79$ & 4.729 & 0.000 \\
\hline
\end{tabular}




\begin{tabular}{|c|c|c|c|c|c|c|c|c|}
\hline \multirow{2}{*}{$\begin{array}{c}\text { Dependent } \\
\text { variables }\end{array}$} & \multicolumn{3}{|c|}{ Women } & \multirow[b]{2}{*}{$\mathrm{p}<\mathrm{t}$} & \multicolumn{2}{|c|}{ Men } & \multirow[b]{2}{*}{ Beta } & \multirow[b]{2}{*}{$\mathrm{p}<\mathrm{t}$} \\
\hline & Predictive variables & $r^{2}$ & Beta & & Predictives variables & $r^{2}$ & & \\
\hline BMI & $\begin{array}{c}\mathrm{VO}_{2} \text { max } \\
\text { Energy acquirement }\end{array}$ & $\begin{array}{l}0.303 \\
0.432\end{array}$ & $\begin{array}{l}0.403 \\
0.389\end{array}$ & $\begin{array}{l}0.004 \\
0.006\end{array}$ & $\begin{array}{c}\text { Energy acquirement } \\
\mathrm{VO}_{2} \max \\
\text { Total fat }\end{array}$ & $\begin{array}{l}0.638 \\
0.728 \\
0.790\end{array}$ & $\begin{array}{l}0.553 \\
0.440 \\
0.259\end{array}$ & $\begin{array}{l}0.000 \\
0.006 \\
0.038\end{array}$ \\
\hline WHR & & & & & $\begin{array}{c}\text { Energy acquirement } \\
\mathrm{VO}_{2} \max \end{array}$ & $\begin{array}{l}0.265 \\
0.284\end{array}$ & $\begin{array}{l}0.618 \\
0.514\end{array}$ & $\begin{array}{l}0.017 \\
0.055\end{array}$ \\
\hline DBP & $\begin{array}{c}\text { Energy acquirement } \\
\mathrm{VO}_{2} \max \end{array}$ & $\begin{array}{l}0.138 \\
0.181\end{array}$ & $\begin{array}{l}0.286 \\
0.224\end{array}$ & $\begin{array}{l}0.029 \\
0.037\end{array}$ & $\begin{array}{c}\text { Total fat } \\
\text { Energy acquirement }\end{array}$ & $\begin{array}{l}0.168 \\
0.193\end{array}$ & $\begin{array}{l}0.572 \\
0.437\end{array}$ & $\begin{array}{l}0.013 \\
0.049\end{array}$ \\
\hline SBP & $\mathrm{VO}_{2} \max$ & 0.191 & 0.437 & 0.004 & $\mathrm{VO}_{2} \max$ & 0.159 & 0.449 & 0.037 \\
\hline $\mathrm{TC}$ & Total fat & 0.415 & 0.944 & 0.000 & $\begin{array}{c}\text { Total fat } \\
\mathrm{VO}_{2} \text { max } \\
\text { Saturated fat }\end{array}$ & $\begin{array}{l}0.461 \\
0.466 \\
0.470\end{array}$ & $\begin{array}{l}1.001 \\
0.093 \\
0.091\end{array}$ & $\begin{array}{l}0.000 \\
0.039 \\
0.043\end{array}$ \\
\hline HDL-C & $\begin{array}{l}\text { Total fat } \\
\mathrm{VO}_{2} \max \end{array}$ & $\begin{array}{l}0.249 \\
0.280\end{array}$ & $\begin{array}{l}0.687 \\
0.148\end{array}$ & $\begin{array}{l}0.000 \\
0.021\end{array}$ & $\begin{array}{c}\text { Total fat } \\
\text { Saturated fat } \\
\mathrm{VO}_{2} \max \end{array}$ & $\begin{array}{l}0.479 \\
0.566 \\
0.632\end{array}$ & $\begin{array}{l}0.924 \\
0.816 \\
0.624\end{array}$ & $\begin{array}{l}0.000 \\
0.004 \\
0.009\end{array}$ \\
\hline LDL-C & $\begin{array}{c}\text { Total fat } \\
\mathrm{VO}_{2} \text { max } \\
\text { Saturated fat }\end{array}$ & $\begin{array}{l}0.462 \\
0.594 \\
0.611\end{array}$ & $\begin{array}{l}1.023 \\
0.177 \\
0.149\end{array}$ & $\begin{array}{l}0.000 \\
0.033 \\
0.045\end{array}$ & Saturated fat & 0.491 & 0.701 & 0.000 \\
\hline TG & $\begin{array}{c}\mathrm{VO}_{2} \max \\
\text { Saturated fat }\end{array}$ & $\begin{array}{l}0.204 \\
0.221\end{array}$ & $\begin{array}{l}0.405 \\
0.139\end{array}$ & $\begin{array}{l}0.011 \\
0.037\end{array}$ & $\begin{array}{c}\mathrm{VO}_{2} \max \\
\text { Saturated fat }\end{array}$ & $\begin{array}{l}0.118 \\
0.281\end{array}$ & $\begin{array}{l}0.430 \\
0.414\end{array}$ & $\begin{array}{l}0.038 \\
0.049\end{array}$ \\
\hline
\end{tabular}

that among men, the association of diet risk factors was more pronounced.

\section{Discussion}

The associations of physical activity, cardiorespiratory fitness, and dietary content with the amount/distribution of body fat, arterial pressure, and plasma lipid-lipoproteins have been extensively investigated separately ${ }^{5-10}$. However, none of these studies incorporated the three responses simultaneously in a single experimental design. This led to a difficulty in establishing the possible relative contributions of the level of physical activity, of cardiorespiratory fitness, and of dietary habits jointly specifically affecting the control of risk factors that cause a predisposition towards cardiovascular disease.

In the present study, simultaneous inclusion in the regression model of information related to physical activity, cardiorespiratory fitness, and dietary content suggests that marked positive variations in risk factors that cause a predisposition towards cardiovascular disease may be explained by the adoption by individuals of a physically more active life style and decreased amounts of total dietary and saturated fat. Nevertheless, depending on the risk factor under consideration, and on the subject's sex, important differences in the proportion of the variation can be attributed to the independent variables.

Looking at body mass index as a reference, it was verified that, in both sexes, estimates of energy demand corresponding to everyday activity and maximal oxygen consumption were singled out as the major components ac- counting for variations in the amounts of body fat. These results reveal that subjects physically less active in everyday life and with lower estimates of maximal oxygen consumption tend to have greater body weight. These findings resemble the results of other studies pointing towards hypoactivity as the major behavioral factor for the development of overweight and obesity ${ }^{20,21}$.

Epidemiological surveys have shown that individuals with a sedentary life style demonstrate a relative risk of 3.1 and 3.8 associated with overweight and obesity, in comparison with their physically more active pairs ${ }^{22}$.

Among men, besides indicators related to the practice of physical activity and cardiorespiratory fitness, the ingestion of total fat was the sole dietary component associated in a significant manner with body mass index. It is probable that the lower proportion of overweight individuals in the feminine sample analyzed may not have been strong enough to lead to the detection of an association between dietary content and body mass indexes in women. In agreement with other studies ${ }^{5-8}$, these findings suggest that inappropriate proportions of fat in the diet may play a more important role than hyperphagia in the greater increase in body weight.

Indicators concerning the practice of physical activity and cardiorespiratory fitness are also significantly associated with a favorable distribution of body fat, especially in men. These findings supply evidence strengthening the hypothesis that higher levels of physical activity may minimize a tendency towards greater centripetal fat concentrations in adult males ${ }^{23}$. Confirming expectations reported in the literature $^{6-8}$, among women modest levels of association between the waist/hip circumference ratios and any selected independent variable were observed in this study. 
A more active everyday life style, coupled with increased estimates of maximal oxygen consumption, demonstrates once again a significant inverse relationship with compromising arterial pressure levels. Negative associations between physical activity, cardiorespiratory fitness, and arterial pressure levels have been reported in other epidemiological and experimental studies ${ }^{24}$.

Several physiological mechanisms can explain the physical activity-maximal oxygen consumption-arterial pressure relationship. Regular practice of aerobic exercise of low to moderate intensity leads to decreased cardiac output and peripheral resistance by reducing neural sympathetic activity ${ }^{25}$. Metabolic adaptation caused by physical activity can also potentiate the advantages of arterial pressure control. In general, the performance of adequate physical effort favors the reduction of plasma levels of norepinephrine, increases circulatory levels of vasodilator substances, and improves hyperisulinism ${ }^{26}$.

Similarly to that which occurs in the regression model in men but not in women, with body mass index as the dependent variable, ingestion of total fat was the dietary component most closely related to arterial pressure levels. Earlier studies point out that mechanisms possibly responsible for the increase of in arterial pressure due to the higher ingestion of fat include altered prostaglandin production ${ }^{27}$, increased sympathetic nervous system activity leading to vasoconstriction ${ }^{28}$, and the influence of the lipid composition of plasma membranes ${ }^{29}$.

In regard to plasma lipid-lipoprotein contents, it can be noted that total and saturated fat ingestion constitute the major predictive variables in the regression model. Taking into consideration the proportion of variation significantly explainable in statistical language, estimates of maximal oxygen consumption are also relatively important for the prediction of plasma lipid-lipoprotein levels. Higher ingestion of total and saturated fat was associated with a less favorable plasma lipid-lipoprotein profile, although estimates of maximal oxygen consumption were inversely associated with total cholesterol, LDL-cholesterol, and triglycerides, and positively associated with HDL-cholesterol. Subjects with the highest amounts of mainly saturated fat in the composition of their diet tended to have higher levels of plasma lipoprotein. On the other hand, values estimated for maximal oxygen consumption were a stronger predictor of HDLcholesterol.

The significant association between fat ingestion and plasma lipid-lipoprotein content noted in the present study was similar to that of experimental studies reported in the literature ${ }^{5-7}$. Nevertheless, evidence from epidemiological studies suggests that these associations could either not be confirmed ${ }^{30}$ or were shown to be only marginally significant ${ }^{31}$.

Some studies in the area have considered that possible methodological limitations justify the conflict observed between epidemiological and experimental results ${ }^{32}$. In this connection, the lesser inter- and intrasubject variability in dietary consumption and, in turn, in the ingestion of macro- and micronutrients, minimizing the discriminatory capacity of the statistical resources involved in the handling of information, should be emphasized. Another limitation is the fragility of some instruments directed towards the everyday eating habits of the subjects involved in these studies.

Relative to maximal oxygen consumption, unanimity of opinion appears to exist concerning its importance in the control of plasma lipid-lipoprotein levels. Nevertheless, an important factor to be considered in the analysis of the results of studies involving the practice of physical exercise is the plasma lipid-lipoprotein profile present at the beginning of the experiment. The more deteriorated this initial profile, the greater the probability of observing significant responses to physical exercise programs. In contrast, subjects who initially have lower concentrations of total cholesterol, LDLcholesterol, and triglycerides and higher concentrations of HDL-cholesterol demonstrate a decreased probability of having alterations in their postphysical exercise plasma lipid-lipoprotein profile ${ }^{33}$.

Physiological mechanisms based on the regular practice of physical exercise lead to a favorable lipid-lipoprotein profile as the result of complex interactions between hormones, enzymes, and receptors. Some studies suggest that increased skeletal muscle or adipose tissue lipoprotein lipase activity, or both during the performance for several hours after exercise associated with a possible decrease in hepatic triglyceride synthesis may constitute a metabolic mode of adjustment favoring decreased concentrations of plasma lipids ${ }^{34}$.

It has occasionally been speculated that favorable modifications in plasma lipid-lipoprotein levels induced by physical exercise may be confounded by concomitant alterations in body weight and body fat distribution profiles, consequent to the higher energy demand caused by the performance of exercise ${ }^{35}$. In this regard, important studies involving well-designed experiments show that regular physical exercise, even when in the absence of significant alterations in body weight and fat content, can also induce substantial improvement in plasma lipid-lipoprotein levels ${ }^{36,37}$.

Similarly to that previously observed ${ }^{38}$, important differences due to sex were found, both in extent and availability of the set of independent variables that may statistically explain variations in plasma lipid-lipoprotein levels. The significant negative association between LDL-cholesterol and triglycerides and estimates of maximal oxygen consumption was more evident in women; in men it was the ingestion of total or saturated fat, or both that explained variations in plasma lipid-lipoproteins. This effect may, plausibly, be sustained by hormonal factors inducing different degrees of interaction between variables associated with the practice of physical activity and dietary content.

Previous studies point to the fact that polyunsaturated fat and, to a lesser degree, monounsaturated fat may eventually raise HDL-cholesterol levels, a desirable effect ${ }^{39}$. Clinical procedures involving modification of dietary content suggest that by partially replacing saturated fat with mono- and polyunsaturated fat favorable alterations in the profile of lipid-lipoproteins can be induced in those with 
hyperlipemia and hypercholesterolemia ${ }^{40}$. However, the inclusion of these micronutrients failed to statistically improve regression models established in the present study. Possibly, the inclusion of variables related to the practice of physical activity and cardiorespiratory fitness in the regression model limited the association between dietary components and risk factors, minimizing the predictive capacity of mono- and polyunsaturated fat.

The weak association observed between dietary consumption of cholesterol and variation in plasma levels of lipid-lipoprotein produced consistent results according to some studies ${ }^{31,39}$, but contradictory results according to others ${ }^{41,42}$. These findings confirm that, despite high individual variability, the ingestion of cholesterol in the diet has a lower association with serum cholesterol than any other dietary component.

Concerning the supply of energy and ingestion of carbohydrates and proteins, no significant association between the presence of these dietary components and risk factors that cause a predisposition towards cardiovascular disease was found. Previous studies have offered evidence that a high level of carbohydrate consumption may result in increase triglyceride levels ${ }^{43}$. Yet, besides the fact that this phenomenon was observed in short-term studies of six-months duration, other studies have not supported these findings ${ }^{44,45}$.

To conclude, a similarity seems to exist between the findings of the present study and previous results obtained from controlled experiments involving information concerning levels of daily physical activity, cardiorespiratory fitness, dietary content, and risk factors that cause a predisposition towards cardiovascular disease. Yet, attention should be given to the possibility that other dietary components not considered in this study also favor risk factors through a variety of possible physiological mechanisms.
For example, decreased sodium ingestion is associated with a reduction in arterial pressure due to less water retention by the organism ${ }^{46}$. Moderate alcohol consumption can have some positive effects by increasing HDL-cholesterol levels. Within acceptable limits, each consumption of $10 \mathrm{~g}$ of alcohol/day induces a $0.6-\mathrm{mg} / \mathrm{dL}$ increase of HDL-cholesterol levels ${ }^{47}$. Certain kinds of soluble fibers, when consumed in large amounts, can reduce the levels of total- and LDLcholesterol, possibly by acting on bile acids in the gut, increasing excretion of cholesterol and reducing the biosynthesis of LDL-cholesterol ${ }^{48}$.

Furthermore, adding to the advantages associated with risk factors that cause a predisposition towards cardiovascular disease, the regular practice of physical activity can improve cardiac function by favoring oxygen supplementation and by increasing the electrical stability of the myocardium ${ }^{49}$. Other potential benefits of such activity, which may aid in the prevention of and recovery from cardiovascular disease include increased glucose tolerance and decreased insulin sensitivity ${ }^{50}$, reduction in platelet aggregation ${ }^{51}$ and plasma fibrinogenesis ${ }^{52}$. Such functional adaptations often fulfill a more important role than traditional risk factors proper and should, therefore, be considered in the analysis of the advantages of the regular practice of physical activity in terms of the reduction in the incidence of cardiovascular disease.

Finally, the close association between daily energy demand, maximal consumption of oxygen, fat ingestion, and risk factors that cause a predisposition towards cardiovascular disease observed in the present study reinforce the recommendation that regular physical exercise and adequate guidance for the ingestion of dietary lipid components should be integrated into programs for the primary prevention of cardiovascular diseases.

\section{References}

1. Bouchard C, Shepard RJ, Stephens T. The consensus statment. In: Bouchard C, Shephard RJ, Stephens T, ed. - Physical Activity, Fitnes, and Health. International Proceedings and Consensus Statement. Champaign, Illinois: Human Kinetics Publishers, Inc., 1994: 9-76.

2. Berlin JA, Colditz GA. A meta-analysis of physical activity in the prevention of coronary heart disease. Am J Epidemiol 1990; 132: 612-28.

3. Blair SN, Horton E, Leon AS, et al. Physical activity, nutrition, and chronic disease. Med Sci Sports Exerc 1996; 28: 335-49.

4. Powell KE, Thompson PD, Caspersen CJ, et al. Physical activity and the incidence of coronary heart disease. An Rev Public Health 1987; 8: 253-87.

5. Esrey KL, Joseph L, Grover SA. Relationship between dietary intake and coronary heart disease mortality: Lipid Research Clinics Prevalence Follow-up Study. J Clin Epidemiol 1996; 49: 211-6.

6. Hu FB, Stampfer MJ, Manson JE, et al. Dietary fat intake and risk of coronary heart disease in women. N Engl J Med 1997; 337: 1491-9.

7. Porrini M, Simonetti P, Testolin G, et al. Relation between diet composition and coronary heart disease risk factors. J Epidemiol Comm Health 1991; 45: 148-51.

8. Trevisan M, Krogh V, FreudenheimJL, et al. Diet and coronary heart disease risk factors in a population with varied intake. Preventive Medicine 1990; 19: 231-41.

9. Eaton CB, Lapane KL, Garber CE, et al. Physical activity, physical fitness, and coronary heart disease risk factors. Med Sci Sports Exerc 1995; 27: 340-6.

10. Adamopoulos PN, Macrilakis K, Papamichael C, et al. Physical activity and relationship with coronary heart disease risk factors. Acta Cardiol 1993; 6: 523-34.
11. Gordon CC, Chumlea WC, Roche AP, et al. Stature, recumbent length, and weight. In: Lohman TG, Roche AF, Martorell R, ed. Anthropometric Standardization Reference Manual. Champaign, Illinois: Human Kinetics Books, 1988: 3-8.

12. Callaway CW, Chumlea WC, Bouchard C, et al. Circunferences. In: Lohman TG, Roche AF, Martorell R, ed. - Anthropometric Standardization Reference Manual. Champaign, Illinois: Human Kinetics Books, 1988: 39-54.

13. Friedewald WT, Levy RI, Frederickson DS. Estimation of the concentration of low density lipoprotein cholesterol in plasma, without use of the preparative ultracentrifuge. Clin Chem 1972; 18: 499-502.

14. Bouchard C, Tremblay A, LeBlanc C, et al. A method to assess energy expenditure in children and adults. Am J Clin Nutr 1983; 37: 461-7.

15. Bruce RA, Kusumi F, Hosmer D. Maximal oxygen intake and nomographic assessment of functional aerobic impairment in cardiovascular disease. Am Heart J 1973; 85: 545-62.

16. American College of Sports Medicine. Guidelines for Exercise Testing and Prescription. $5^{\text {th }}$ Edition. Philadelphia: Williams \& Wilkins, 1995.

17. Robergs RA, Roberts SO. Exercise Physiology: Exercise, Performance, and Clinical Applications. New York: McGraw-Hill, 1996.

18. Food and Nutrition Board. Recommended Dietary Allowances. $10^{\text {th }}$. Edition. Washington, D.C.: National Academy Press. 1989.

19. Sociedade Brasileira de Cardiologia - Consenso brasileiro sobre dislipidemias: detecção, avaliação e tratamento. Arq Bras Cardiol 1996; 67: 113-28. 
20. King AC, Tribble DL. The role of exercise in weight regulation in non-athletes. Sports Medicine 1991; 11:331-49.

21. Lavery MA, Loewy JW. Identifying predictive variables for long-term weight change after participation in a weight loss program. J Am Diet Assoc 1993; 93: 1017-24.

22. Williamsom DF. Recreation physical activity and ten-year weight changes in a US national cohort. Int J Obes 1993; 17: 279-85.

23. Després JP, Nadeau A, Tremblay A, et al. Physical training and changes in regional tissue distribution. Acta Med Scand Suppl 1988; 723: 205-12.

24. Hagberg JM. Exercise, fitness and hypertension. In: Bouchard C, Shephard RJ, Stephens T, ed. - Exercise, Fitness and Health: A Consensus of Current Knowledge. Champaign, Illinois: Human Kinetics Publishers, 1990: 455-66.

25. Fagard RH, Tipton CM. Physical activity, fitness and hypertension. In: Bouchard C, Shephard RJ, Stephens T, ed. - Physical Activity, Fitness and Health: International Proceedings and Consensus Statement. Champaign, Illinois: Human Kinetics, 1994: 633-55.

26. Marceau M. Effects of different training intensities on 24-hours blood pressure in hipertensive subjects. Circulation 1993; 88: 2803-11.

27. Galli C. Dietary influences on prostaglandin synthesis. Adv Nutr 1980; 3: 95-126.

28. Schwartz JH, Young JB, Landsberg L. Effect of dietary fat on sympathetic nervous system activity in the rat. J Clin Invest 1983; 72: 361-370.

29. Anderson JW. Nutrition management of diabetes mellitus. In: Shils ME, Young VR, ed. - Modern Nutrition in Health and Disease. Philadelphia: Lea \& Febiger, 1988: 1201-29.

30. Shekelle RB, Shryock MA, Oglesby P, et al. Diet, serum cholesterol, and death from coronary heart disease. The Western Electric Study. NEngl J Med 1981; 304: 65-70.

31. Kushi LH, Lew RA, Stare FJ, et al. Diet and 20-year mortality from coronary heart disease. The Boston-Ireland Diet Study. N Engl J Med 1985; 312: 811-8.

32. El Lozy M. Dietary variability and its impact on nutritional epidemiology. J Chronic Dis 1983; 36: 237-49.

33. Després JP, Lamarche B, Bouchard C, et al. Exercise and the prevention of dyslipidemia and coronary heart disease. Int J Obes 1995; 19(4 Suppl): S45-S51.

34. Wood PD, StefanickML. Exercise, fitness and Atherosclerosis. In: Bouchard C, Shephard RJ, Stephens T, ed. - Exercise, Fitness and Health: A Consensus of Current Knowledge. Champaign, Illinois: Human Kinetics Publishers, 1990: 409-23.

35. Després JP, Pouliot MC, Moorjani S, et al. Loss of abdominal fat and metabolic response to exercise training in obese women. Am J Physiol (Endocrinol Metab) 1991; 261: E159-67.

36. Katzel LI, Bleecker ER, Colman EG, et al. Effects of weight loss vs aerobic exercise training on risk factors for coronary disease in healthy, obese, middleaged and older men. JAMA 1995; 274: 1915-21.
37. Lamarche B, Després JP, Pouliot MC, et al. Is body fat loss a determinant factor in the improvement of carbohydrate and lipid metabolism following aerobic exercise training in obese women? Metabolism 1992; 41: 1249-56.

38. MacAuley D, McCrum EE, Stott G, et al. Physical activity, lipids, apolipoproteins, and Lp(a) in the Northern Ireland Health and Activity Survey. Med Sci Sports Exerc 1996; 28: 720-36.

39. Sacks F. Dietary fats and coronary heart disease. J Cardiovasc Risk 1994; 1: 3-8

40. Hegsted DM, Ausman LM, Johnson JA, et al. Dietary fat and serum lipids: an evaluation of the experimental data. Am J Clin Nutr 1993; 57: 875-83.

41. McGee DL, Reed DM, Yano K, et al. Ten-year incidence of coronary heart disease in the Honolulu Heart Program. Relationship to nutrient intake. Am J Epidemiol 1984; 119: 667-76.

42. Shekelle RB, Shryock AM,Paul O, et al. Diet, serum cholesterol, and death from coronary heart disease. The Western Electric Study. NEngl J Med 1981; 304: 65-70.

43. Knuiman JT, West CE, Katan MB. Total cholesterol and high density lipoprotein cholesterol levels in populations differing in fat and carbohydrate intake. Arteriosclerosis 1987; $7:$ 612-9.

44. West CE, Sullivan DR, Katan MB, et al. Boys from populations with high-carbohydrate intake have higher fasting triglyceride levels than boys from populations with fat intake. Am J Epidemiol 1990; 131: 271-82.

45. Garg A, Banthe JP, Henry RR, et al. Effects of varying carbohydrate content of diet in patients with non-insulin-dependent diabetes mellitus. JAMA 1994; 271: 1421-8.

46. Cutler JA, Follmann D, Elliott P, et al. An overview of randomized trials of sodium reduction and blood pressure. Hypertension 1991; 17(Suppl I): I27-I33.

47. Marrugat J, Elosua R, Covas MI, et al. Amount and intensity of physical activity, physical fitness, and serum lipids in men. Am J Epidemiol 1996; 143: 562-9.

48. Glore SR, Van Treeck D, Knehans AW, et al. Soluble fiber and serum lipids: a literature review. J Am Diet Assoc 1994; 94: 425-36.

49. Haskell WL, Leon AS, Caspersen CJ, et al. Cardiovascular benefits and assessment of physical activity and physical fitness in adults. Med Sci Sports Exerc 1991; 24(Suppl): S201-20.

50. Heath GW, Gavin JR, Hinderliter JM, et al. Effects of exercise and lack of exercise on glucose tolerance and insulin sensitivity. J Appl Physiol 1983; 55: 512-7.

51. Rauramaa R, Salonen JT, Seppanen K, et al. Inhibition of platelet aggregability by moderate-intensity physical exercise: a randomized clinical trial in overweight men. Circulation 1986; 74: 939-44.

52. Lakka TA, Salonen JT. Moderate to high intensity conditioning leisure time physical activity and high cardiorespiratoty fitness are associated with reduced plasma fibrinogen in eastern Finnish men. J Clin Epidemiol 1993; 48: 1119-27. 